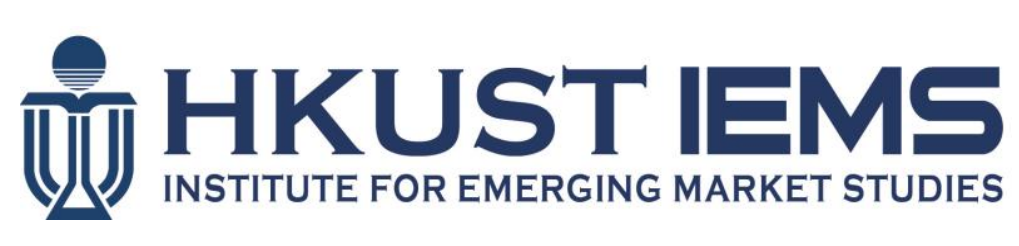

\title{
Global Technology Leadership: The Case of China
}

\author{
Naubahar SHARIF
}

HKUST IEMS Working Paper No. 2015-11

February 2015

\begin{abstract}
HKUST IEMS working papers are distributed for discussion and comment purposes. The views expressed in these papers are those of the authors and do not necessarily represent the views of HKUST IEMS.
\end{abstract}

More HKUST IEMS working papers are available at: http://iems.ust.hk/WP 


\title{
Clobal Technology Leadership: The Case of China
}

\author{
Naubahar SHARIF
}

HKUST IEMS Working Paper No. 2015-11

February 2015

\begin{abstract}
Over the last century and a half, global technological leadership has shifted from Great Britain to the United States. In this paper we argue that China is positioning itself to assume global leadership in technology within the coming few decades. We identify three sources of competitive advantage for China's ascent in the global technology stakes: its massive domestic market, its centralized power and willingness to employ state-sponsored industrial policy and government support, and the process of globalization that continues to transform markets worldwide. After acknowledging skeptical views of China's capacity to achieve global technology leadership, we survey the present state of affairs and assess its prospects for growth based on statistical evidence and multiple illustrative examples. We argue that the three sources of competitive advantage we explicate offer China a path to imminent global technological leadership.
\end{abstract}

\section{Author's contact information}

Naubahar Sharif

Division of Social Science

The Hong Kong University of Science and Technology

E: sosn@ust.hk 


\title{
GLOBAL TECHNOLOGY LEADERSHIP: THE CASE OF CHINA
}

\begin{abstract}
:
Over the last century and a half, global technological leadership has shifted from Great Britain to the United States. In this paper we argue that China is positioning itself to assume global leadership in technology within the coming few decades. We identify three sources of competitive advantage for China's ascent in the global technology stakes: its massive domestic market, its centralized power and willingness to employ state-sponsored industrial policy and government support, and the process of globalization that continues to transform markets worldwide. After acknowledging skeptical views of China's capacity to achieve global technology leadership, we survey the present state of affairs and assess its prospects for growth based on statistical evidence and multiple illustrative examples. We argue that the three sources of competitive advantage we explicate offer China a path to imminent global technological leadership.
\end{abstract}

\section{Keywords:}

Technology leadership, Innovation, Industrial policy, Globalization, China 


\section{GLOBAL TECHNOLOGY LEADERSHIP: THE CASE OF CHINA}

\section{Historically Changing Tides}

China's economic power cannot be ignored but, its obvious competitive advantages notwithstanding, few observers include technology and innovative capacity among its strengths. Here we survey China's prospects for achieving global leadership in technology, which we believe are strong. Should China achieve parity with traditional technology leaders, it would alter the global technology landscape profoundly, given the scale at which it would operate.

We define 'technological leadership' as a function of four factors. The first is the 'headline' figure of research and development (R\&D) intensity (including absolute amounts of $\mathrm{R} \& \mathrm{D}$ expenditure), and the remaining three combine commonly cited R\&D inputs and R\&D outputs: number of $R \& D$ personnel, number of scientific publications (including citations in other scientific publications), and patents (more specifically, Patent Cooperation Treaty patent applications). To be sure, the spectrum of innovation leadership goes beyond this narrow definition based only on distinctly measurable statistics on $\mathrm{R} \& \mathrm{D}$, publications and patents. Innovation in China — and innovation in general-encompasses many other types of improvements including advances in cost efficiency, value for money, rapid commercialization, new business models, new applications of existing technologies, etc. (cf. Li 2013: 9).

After thirty years of fast-paced economic growth since Deng Xiaoping steered the great behemoth towards economic modernization, China has begun to emerge not only as a leading economic superpower, but also as a technological superpower. Exploitation of the Chinese market becomes especially relevant for the United States and many western European countries as both regions have struggled in the wake of 
the Great Recession of 2009. Against this backdrop, policymakers and entrepreneurs in both regions have sought to further develop and utilize science, technology, and innovation — domestically and abroad — as their engines for economic growth.

The United States and much of Western Europe have, however, been mired in economic turmoil and, in some cases, political chaos since the Recession, although signs of steady improvement have begun to emerge, especially in the United States. Still, investment by Western powers in education, research and technology are either stagnating or on the decline. Meanwhile, China continues to strengthen its innovation system; the rate of spending on research and development (R\&D) in China outpaces overall economic growth. In terms of R\&D intensity, in 2013 China spent US\$191 billion (current prices) or 2.08 per cent of its rapidly increasing GDP on R\&D, placing it second only to the United States (in terms of absolute amount of annual expenditure on R\&D) (Ministry of Science and Technology, 2014). Moreover, there were over 3.2 million R\&D personnel in China in 2013. The rapid expansion of degree production in China in science and engineering fields is particularly noteworthy as it is more than double US levels. In 2010, science and engineering degrees represented 40 per cent of all new university degrees awarded in China (compared with just 15 per cent in the United States). The yawning gap is most evident in engineering, which represents nearly 30 per cent of all new university degrees awarded in China, compared with just 6 per cent in the United States. In absolute terms, China's science and engineering doctorate production has grown by an average of 18 per cent per year since 1998 (thanks in part to a lower base level). 
By 2012, China's S\&E doctorate production had surpassed US levels (National Science Foundation [NSF] 2014). ${ }^{1}$

According to Thomson Reuters' Science Citation Index, for the period covering 2001-2011, China ranked second in the world in research output as measured by number of papers published in research journals (Thomson Reuters 2011). China also ranked fifth in number of citations in 2013 and fourth in number of highly cited papers published in 2003-2013, which rank in the top 1 per cent by citations for field and year indexed in the Web of Science (Institute of Scientific and Technical Information of China, 2013). In 2013, China trailed only the United States and Japan in patent filings under the Patent Cooperation Treaty (PCT) administered by the World Intellectual Property Office (World Intellectual Property Organization 2014). Furthermore, in 2013, two large Chinese telecommunications equipment manufacturers, ZTE and Huawei Technologies, filed 2,309 and 2,094 patents, respectively, which ranked them second and third in the worldwide ranking of top PCT patent applicants. At the US Patent and Trademark Office, the number of patent applications originating in China grew 14 per cent from 2012 to 2013 alone, a rate that is higher than those of the other top countries and regions (the United States, Japan, Germany, South Korea and Taiwan) (US Patent and Trademark Office 2014).

Despite these indicators, there exists considerable skepticism over China's capacity to attain global technological leadership. George Gilboy, a research affiliate at Massachusetts Institute of Technology, wrote in Foreign Affairs, in 2004, that 'Chinese firms ... forgo investment in long-term technology development and

\footnotetext{
${ }^{1}$ Even within the United States, Chinese-born students have been earning a rising number of graduate degrees. Chinese-born students now dominate US doctorate education in critical fields, especially engineering, math, and the physical sciences. Over the period 1987-2007, the one country from which United States science and engineering degree recipients dominated was China. By 2007, students from China received 11 per cent of all United States science and engineering doctoral degrees awarded (Goldman Sachs, 2010).
} 
diffusion ... [and] rely heavily on imported foreign technology and componentsseverely limiting the country's ability to wield technological or trading power for unilateral gains' (Gilboy 2004, 33-4). Gilboy has highlighted the 'processing trade' business model that has prevailed in China, particularly over the last two decades. Under this model, domestic firms or subsidiaries of foreign firms have been content to import high-value-added components for which the R\&D is conducted abroad, assembling those components in China and exporting the finished goods to overseas markets.

Gilboy is not alone. Other notable commentators and analysts as well as academics have written about the propensity on the part of Chinese firms to opt for a short-term, low-technology, low-profit mode of operation, hindering their prospects for moving up the value-added chain to become true global leaders in technology. For instance, in 2012, David Shambaugh of George Washington University, in discussing the attempts of Chinese firms to 'go out' and 'go global', identified the short-term perspective taken by many Chinese companies as a key general weakness (Shambaugh 2012). ${ }^{2}$ Dan Breznitz and Michael Murphee, professors at the Georgia Institute of Technology, argued in 2011 that China has settled on merely keeping pace with technological advances elsewhere, pursuing innovation only in later, less consequential stages of the production process (Breznitz and Murphee 2011). The journalist Thomas Friedman argued, in September 2012, that driving economic growth through entrepreneurship and innovation depends on a culture of trust, observing that 'China has a huge trust deficit', a lingering remnant of Maoism. Prior to the opening of China in 1979 , the Communist Party had destroyed the old system

\footnotetext{
${ }^{2}$ Within the innovation literature (cf. Fagerberg, Mowery and Nelson, 2005) it is acknowledged that a long time horizon is a key ingredient in enabling companies to become successful global innovators.
} 
of trust among 'villages and families', but has yet to build a new system 'because it would mean ceding the party's arbitrary powers' (Friedman 2012, 31).

It is certainly true that, so long as wages in China are lower than those in Western countries, Chinese firms are less motivated to invest in labor-saving advanced technologies than their counterparts in competing countries. However, such skepticism overlooks several important factors that have positioned China to compete for global technological leadership. We see three distinct sources of competitive advantage that we believe China will leverage in developing its capacity for technological innovation. One of these factors - a large and rapidly growing domestic market — is no secret, while the other two - a firm government hand in industrial policy and globalization — complement the first factor, market size, in providing China with a path to global technological leadership.

China's rapidly growing domestic market—now the second largest in the world - will continue to grow and is likely to surpass the US market around 2020. As market size is an important determinant of innovation activities, burgeoning demand will drive Chinese companies to continuously advance their technological capabilities to profit from successful innovation, providing a global advantage such as no other economy enjoys.

In spite of China's openness to market forces, however, Beijing's autocratic system of governance largely persists, providing ample room for the Chinese government to enact and implement industrial and innovation policy to enhance the technological capabilities of Chinese companies to an extent that mature Western market-oriented economies and democratic governments cannot match. This represents the second advantage we discuss here. Able to enact policy facing little or no opposition, Beijing can steer economic development as it sees fit. Benefiting from 
China's so-called 'indigenous innovation' strategy, Chinese companies enjoy government support of $R \& D$, enabling them to develop technologies independently and to own intellectual property rights. Large-scale government grants and lowinterest loans from state-owned banks under the framework of the indigenous innovation strategy provide Chinese firms with strong incentives to become global technological leaders.

Finally, intensified globalization will continue to benefit Chinese companies in the coming decades, providing a third advantage in its drive to become a worldwide force in technology. On the one hand, Chinese firms need not develop every advanced technology on their own in a globalized world. Backed by the government's 'go global' strategy, they can acquire such technologies through mergers and acquisitions abroad. On the other hand, as the economy grows and indigenous companies move up the technological ladder, foreign multinational corporations will be increasingly tempted, or perhaps feel compelled, to bring their advanced products to China, eventually even patenting their cutting-edge technologies there. This will in turn generate demonstration, labor mobility, and competition effects—or 'spillovers' - to benefit local firms.

With all these opportunities looming on the horizon, Chinese companies are sparing no effort to seize them in an effort to possibly assume global leadership in technology and innovation. After tracing the trajectory of global technological leadership as indicated in the economics and innovation literature, we subsequently consider each of the three factors we have identified as competitive advantages for China — market size, governmental power, and globalization—in greater depth.

\section{Trajectory of Global Technological Leadership}


In this section, we follow the trajectory of global technological leadership by reviewing salient studies in the economic growth and innovation literature that document the quest to attain, or retain, global technological leadership. In this review we aim not to uncover the historical reasons behind other countries' attainment of technological superiority, but rather to trace how technological leadership has moved over time through a series of geographic locations. Our goal then is to show that this trend in technological leadership continues to this very day, with China likely to be the next torchbearer.

Our survey begins with the British Industrial Revolution, extending to the present day. The levering of technology for the purpose of attaining competitiveness through economic and military leadership during the Industrial Revolution in Britain has attracted considerable scholarly attention (cf. Kranzberg 1967; Mokyr 1990). Advances in the iron, cotton and steel industries over the 70 -year period of the Industrial Revolution acted as catalysts for further technological change in associated industries and had a cascading effect as the impact of the initial technological advancements were diffused throughout British society. These technological changes in turn led to economic, political, and social changes. ${ }^{3}$ By the end of the Industrial Revolution, Britain had developed a considerable technological lead over other nations to the extent that, at the First World's Fair held in London in 1851, visitors including merchants, engineers, technicians, capitalists and politicians were left awestruck at the technological sophistication of British industry that was on display in the Crystal Palace, the massive structure in which the exposition was staged.

The British lead in technology (and economic might) began to attract the attention of large continental European countries, notably Germany and France.

\footnotetext{
${ }^{3}$ However, the relationship was not uni-directional. In some instances, political changes (new regulations, laws, etc.) led to technological advancements.
} 
Germany began to industrialize soon after the British, and when it became politically unified in 1870 it also became economically unified. The newly unified German banking sector and monetary system fed industrial development, which was further supported by the German railroad boom that began in the 1840s and continued through the period of political and economic unification. In Germany and elsewhere in Continental Europe, technology transfer from Great Britain was an important factor in the shift of technological leadership beyond the borders of Britain (despite Britain's best attempts to restrict it). By the turn of the twentieth century, however, the torch of global technological leadership had shifted from Europe to the United States. ${ }^{4}$

The literature on American global technological leadership is voluminous-in no small measure because American technological leadership, which to be sure has been threatened over the last century, has yet to be fully superseded. The literature on American leadership can be traced back to Solow (1956), who identified technical change as the source of American economic growth. ${ }^{5}$ Solow's study spawned additional scholarship along similar lines, including Habbakuk (1962), whose study reinforced de Tocqueville's assertion in the 1800s that the United States had 'made such rapid progress in trade and manufacturers' (2002: 441) that, 'in a number of industries, American equipment was ... superior to [that of] the English' (Habbakuk 1962: 4).

\footnotetext{
${ }^{4}$ Here, we do not discuss the reasons for the British fall from global technological dominance. Studies suggest that it was due in part to its having assumed leadership so early (cf. Veblen 1939; Kindleberger 1961).

${ }^{5}$ Empirical growth accounting began with the famous studies of Robert Solow (1957), and also Moses Abramovitz (1962). Their procedure for calculating technical progress was to deduce the growth in output attributable to growth in capital and labor (multiplied by their respective factor prices) and ascribe the 'residual' growth in output to technical progress. The most striking feature of early investigations of growth accounting was the size of the Solow residual. For example, Solow (1957) calculated that only 12.5 per cent of growth in output per capita in the United States from 1909 through 1949 was due to factor accumulation-leaving 87.5 per cent to be explained by technical progress. Later work refined these estimates by allowing for improvements in human capital, but the residual remained large.
} 
A decade after Solow's seminal contribution, Denison and Poullier (1967) demonstrated the prominence of advanced technology among the myriad factors that explained US leadership in total factor productivity during the quarter century following World War II (these differences held not just in the aggregate but in almost all industries). Maddison (1982) offered data to show that American productivity and per capita income had overtaken Britain's by the dawn of the 1900s. He shows that by 1913, productivity and per capita income in the United States was significantly higher than in England, and higher still than in Continental Europe (Maddison 1982: 212). Importantly, American's productivity advantage was due in no small part to its leadership in technological innovation.

Chandler (1977) and Lazonick (1988) have both shown how, by World War I, American firms (especially in chemical and electronic industries) had established first-class industrial laboratories that were insulated from more immediate corporate pressures to solve shop-floor problems, thereby allowing them to dedicate their efforts to invention. Both studies demonstrate how this adaptation was facilitated by more general changes in corporate management and structure. ${ }^{6}$

More recently, Richard Nelson (1990) described how US firms were world leaders in developing leading-edge technologies from the mid-1940s to the end of the 1970s (their exports in leading-edge technologies accounted for the bulk of trade on world markets, and their overseas branches were dominant firms in host countries). Nelson's (1990) contribution is noteworthy for our purposes not least because he argued unequivocally that one central component of post-war US technological dominance was advanced technology. He showed how the last half of the nineteenth century was the great age of American invention and innovation in consumer and

\footnotetext{
${ }^{6}$ Lazonick in particular documents how British (and to a lesser extent, German) firms were slower to adopt new structures such as top-down hierarchical management (which allowed for the establishment of sub-organizations, specialized by regions, product, or R\&D).
} 
producer goods, and also an era during which the system of interchangeable parts (cf. Hounshell 1984) was being rapidly deployed in a number of manufacturing industries. These developments, combined with a rapidly growing US domestic mass market and an expanding rail and communications network led to the rise of large corporations in a number of industries dealing in products as varied as (low-cost) steel (and by extension, innovative uses of steel such as steel skeleton building construction), sewing machines, typewriters, matches, and refrigerated meat. These mammoth diversified conglomerate corporations were pioneers in mass production, as embodied in the huge plant, the rigid assembly line, the standardized product, and the long production run. They had developed a clear technological edge as compared with their British and Continental European counterparts that enabled them to dominate global production and trade.

All of this meant that the United States came to be viewed as the 'leader' under the 'catching-up hypothesis', while other countries were 'followers'. Abramovitz (1986) articulated this hypothesis well in stating that 'countries that are technologically backward have a potentiality for generating growth more rapid than that of more advanced countries, provided their social capabilities are sufficiently developed to permit successful exploitation of technologies already employed by the technological leaders' (p. 390). Although American technological dominance was accompanied by the decline of productivity in Britain, America's dominance has not remained uniformly strong throughout the twentieth century, having faced several threats, and here we briefly consider the Japanese threat that, especially in the 1980s, came to preoccupy American thought.

Even before Japan's technological rise in the 1970s and 1980s, however, Edward Ames and Nathan Rosenberg (1963) had given theoretical consideration to 
the possibility of falling behind, overtaking, and surpassing other countries economically, concluding that arguments that imply that troubles connected with leadership and industrial 'aging' doom early leaders to declining productivity are not persuasive. They hold that outcomes turn on a variety of empirical conditions, the presence of which are uncertain and not foreordained (Ames and Rosenberg 1963: 397, quoted in Abramovitz 1986).

More recently, Freeman (1987), Hobday (cf. 1995) and Lall (1997) demonstrated that Japan's focus on innovation and technological advance propelled it into the position of 'leader' (Hobday 1995: 20-21) among East Asian nations following World War II. While Japanese technological success was initially (and simplistically) attributed to copying, imitating, and importing foreign technology, as Japanese products and processes began to out-perform American and European products in more and more industries it became evident that this explanation was no longer adequate. Moreover, as Japanese industrial R\&D expenditures (as a proportion of civil industrial net output) surpassed those of the United States in the 1970s and total civil R\&D as a fraction of GDP surpassed that of the United States in the 1980s, the Japanese performance could now be explained quantitatively-in terms of R\&D intensity — especially as Japanese R\&D was highly concentrated in the fastest growing civil industries, such as electronics. US patent statistics in the 1980s showed that the leading Japanese electronics firms outstripped American and European firms in these industries, not just in domestic patenting but also in foreign patents (Freeman 1987). Other studies described how there were additional qualitative factors at play in Japan that better explained Japanese technological superiority. These included the higher quality and technological sophistication of new products and processes (Grupp and Hofmeyer 1986; Womack et al. 1990), shorter lead times (Mansfield 1988), rapid 
diffusion of technologies (such as robotics) (Fleck and White 1987; Mansfield 1989), and, crucially, the integration of $\mathrm{R} \& \mathrm{D}$, production, and technology imports at the firm level (Takeuchi and Nonaka 1986; Freeman 1987).

While several smaller countries—-such as Israel, Sweden, Denmark, Finland Korea, Taiwan, and Singapore- have subsequently focused intense efforts on taking a 'slice' of the technological leadership pie, only China seems to be in a position from which it can truly challenge and usurp American technological hegemony. It is on China-particularly its competitive advantages in market size, governmental power, and globalization - that we focus in the remainder of this paper.

\section{Becoming the World's Largest Market}

Since American economist Jacob Schmookler advocated the demand-pull theory of technological change and innovation in the 1960s (Schmookler 1966), economists have argued that market size is an important determinant of innovation activities. With new products the general rule is that the greater the demand, the greater the revenue; or, alternatively, the more efficient the production process, the greater the aggregate cost savings. This implies, first, that a growing market with growing demand will lead to increasing returns on investment in innovation, other things being equal, so that companies are incentivized to introduce new products to reap the increasing returns. Because geographical proximity and linguistic and cultural similarity can reduce transaction costs and facilitate technology and knowledge acquisition, domestic market size remains a crucial factor in driving firmlevel innovation strategy and technological competitiveness. This is true even in today's globalized world in which multinational corporations sell so many products outside their home markets. 
We are witnessing scale benefits in China that remind us of what transpired in the United States, especially following World War II. During the quarter century that followed the war, US firms led the world in developing and deploying leading-edge technologies, claimed the largest worldwide share in many if not most export goods, and through their overseas branches often dominated host country markets. According to the economists Richard Nelson and Gavin Wright, these developments reflected longstanding American dominance in mass production industries, which can be attributed in turn to ready access to natural resources and the world's largest domestic market (Nelson and Wright 1992). Resource- and capital-intensive American manufacturing firms operated on a much larger scale than their counterparts elsewhere, as many European-based innovations were actually developed and brought to market in the United States due to the economies of scale American firms enjoyed. We expect to see a similar dynamic — albeit as a result of a different set of underlying conditions (as compared with the US) - play out in the massive Chinese market.

Thus, China's emergence as a rapidly growing major market offers it a unique advantage, one the likes of which no nation other than the United States has hitherto enjoyed. As Chinese consumers' expectations regarding price, quality, and features differ markedly from those of consumers in developed economies, it is local Chinese firms (as opposed to foreign firms) who are best situated to satisfy the singular tastes of the Chinese market. Chinese companies seeking global market share have therefore accumulated both significant cash flow and considerable business experience (from their efforts in the domestic Chinese market) that adds to their competitiveness. Additionally, the size and speed of China's market expansion allows local companies to move rapidly along the learning curve. Many Chinese firms take advantage of the larger size of the Chinese market and increased opportunities to interact with users, 
expediting the speed with which new products are introduced to the market and improved thereafter. Just as American firms achieved leadership in the production of nearly all major raw materials by the end of the nineteenth century, so Chinese manufacturers today are leading producers in seven of the twenty-two two-digit manufacturing sectors. Indeed, China leads the world in producing the most steel, cement, automobiles, fertilizer, and more than 200 other products (Xinhua News Agency 2013).

Brandt and Thun (2010) examined the development of the automobile, construction equipment, and computer numerically controlled machine tools industries in China and argued that the growth of the domestic market has two impacts on the development of Chinese firms. On the one hand, the rapid growth of low-end segments in these industries allows more capable domestic firms to leverage scale, experience, and revenue to upgrade and therefore shift to higher-end segments. On the other hand, the lure of a rapidly growing market and competitive pressures incentivize foreign firms to localize their sourcing in order to lower costs and increase responsiveness to Chinese consumer demand. This in turn generates technological spillovers to upstream and downstream domestic firms.

This integration of mass production strength with the world's second-largest economy has led forecasters at Goldman Sachs, Standard Chartered Bank, the Conference Board, and the Economist to predict that the Chinese economy will be twice as large as the US economy by 2030, although China's Gross National Income - GNI - per capita is likely to be about half that of the United States (Economist 2011; Adam 2010). Consistent with these predictions, Justin Yifu Lin, the former chief economist of the World Bank, has also argued that although China's GNI per capita in Purchase Power Parity (PPP) terms was only 21 per cent of that of 
the Untied States in 2008, it should grow at an eight per cent pace over the next 20 years. He predicted that by 2030 between 100 and 150 of the largest Fortune 500 companies in the world will be Chinese firms (Anderlini 2013). If these forecasts prove true, the capacity of Chinese firms to continuously leverage the advantage of their large home market to enhance their technological competitiveness will almost certainly be a major success factor.

\section{Beijing's Visible Hand}

On the way to becoming global technological leaders, Chinese companies have benefited significantly from the Chinese government's industrial policy, which is unmatched in scale and strength by Western standards. Analysts who have studied the success of high-technology industries in the United States acknowledge that American technological leadership in the early postwar era reflected massive private and public investments in R\&D and scientific and technical education after World War II. Those countries, including China, that have adopted the US model have spared no effort to boost their own state-backed R\&D investments.

Even though the United States is currently by far the largest R\&D performer (US\$453 billion in 2012, PPP), accounting for about 31 per cent of the global total (a figure that has nevertheless declined from 38 per cent in 1999), China has made significant progress by becoming the second-largest global performer of R\&D (US\$293 billion in 2012, PPP), accounting for about 20 per cent of the global total (OECD 2014). The pace of real growth in China's overall R\&D expenditure over the past ten years (1999-2009) in particular remains exceptionally high, at about 20 per cent annually. In comparison with that of the U.S., China's R\&D expenditure-to-GDP ratio remains relatively low (2.08 per cent in 2013), but it has more than doubled from 0.8 per cent in 1999 (NSF 2014). At the 'National Science, Technology and 
Innovation Convention' held on July 6-7, 2012, President Hu Jintao vowed to raise the ratio to 2.5 per cent by 2020. Indeed, China had already, in March 2006, launched its National Mid- and Long-Term Science and Technology Development Plan for 2006-2020, in which the term 'indigenous innovation' — whereby Chinese firms undertake independent $\mathrm{R} \& \mathrm{D}$ and claim intellectual property rights — was first mentioned (Xinhua News Agency 2012; Cao et al., 2006).

The Plan represents the Chinese leadership's ambition to sustain economic growth and social development through indigenous innovation and increased government-led R\&D investments. The Plan demonstrates the Chinese authorities' view that innovation is critical to both the domestic economy's long-term health and Chinese companies' global competitiveness. If President Hu's target is met and China becomes the world's largest economy by around 2020, then the total R\&D investment in China by that time will equal that of the United States (which in turn will help Chinese firms increase their technological sophistication).

The use of industrial policy to help domestic companies upgrade technological capabilities is widespread globally. Michael Lind, Policy Director at the New America Foundation in Washington, D.C., observed that even in the United States government-enacted industrial policy facilitated its growth as an industrial powerhouse (Lind 2012). Such policies have their roots in Hamiltonian economic philosophy, which holds that a big country needs big organizations to succeed and that the federal government in particular should partner with private enterprise to build roads and schools, guarantee loans, and finance scientific research, thereby providing resources and infrastructure that individual businesses lack. ${ }^{7}$

\footnotetext{
${ }^{7}$ Under this Hamiltonian approach the American government sponsored such massive infrastructure projects as the Erie Canal, the transcontinental railroad, land-grant universities, the Eisenhower Interstate Highway System and the nationwide network of airports. This helped to create within the United States a huge interconnected marketplace in which companies such as Standard Oil, General
} 
Most of the centralized power that enabled China to run a planned economy remains in place, so the government is still able to play a significant role in shaping increasingly market-oriented economic activities. The Chinese government therefore has more policy instruments at its disposal than do its counterparts in the West, and this enables it to facilitate technological learning on the part of indigenous firms. For example, in 2006 the Chinese government announced a comprehensive policy to promote the wind power industry and develop a large domestic market by mapping wind power resources and regulating wind farms. The policy also promoted indigenous R\&D investment and established technological standards and a quality inspection system for wind turbines (National Development and Reform Commission 2006). This policy, together with wind power concession projects and a preferential feed-in tariff policy launched by the Chinese government in 2003, led to the rapid development of the Chinese wind turbine manufacturing industry (Lewis 2011).

Before 2000, the domestic wind turbine market in China relied almost exclusively on equipment imported from Europe; installed wind power capacity in China was virtually zero as recently as 2005 . However, the installed capacity doubled each year from 2006 to 2009 and, by 2010, one of every three newly installed wind turbines worldwide was located in China. By the end of 2013, cumulative installed capacity amounted to 91.4 gigawatts, the highest in the world, accounting for 29 per cent of the world's total. As the domestic market grew, so did the indigenous industry. In 2013, the top four wind turbine manufacturers in the country - Goldwind, Guodian United Power, Mingyang Wind Power, and Sinovel-were among the top ten players in the world (Chinese Wind Energy Association 2014). Among them, Goldwind is the

Motors, US Steel, General Electric and Sears Roebuck found room to prosper and grow. This was a time during which the American government - and the military in particular-led the way in financing innovation in its early stages. Government-financed research and procurement fueled industries that produced, among other things, the hybrid seed, radar, synthetic rubber, the microchip, the global positioning system, and the Internet. 
world's largest wind turbine company engaged in the next-generation technology of direct-drive permanent magnets, eliminating the need for a gearbox. Without a gearbox (i.e. fewer moving parts), the chance of costly mechanical failure is reduced dramatically and the turbine's lifespan is increased. With 20 per cent of its 4,000 staff involved in R\&D activities and its turbines operating in six continents, Goldwin has been recognized twice (in 2011 and 2012) by the MIT Technology Review as one of the 50 most-innovative companies in the world.

In addition to bolstering the wind turbine industry, the Chinese government has also targeted a series of 'strategic emerging technologies', which include environmental technology, information and telecommunications, biotechnology, advanced manufacturing, renewable energy, advanced material, and green vehicles. Beneficial policies that promote such industrial development include large-scale government grants, tax concessions, easy access to bank loans, and supportive policies regarding intellectual property, standardization, and human resources. According to Bloomberg, in 2010 China invested more resources in clean energy and related technologies than any other country. Chinese commercial investment in clean energy technologies, which Bloomberg defines to include wind, solar, biofuels, and energy efficiency, rose almost exponentially from less than US\$1 billion in 2004 to US $\$ 53$ billion in 2010, with the bulk of China's investment in wind energy — $\$ 45$ billion (NSF 2012).

There is, of course, considerable concern in the United States and elsewhere that China's growing power is due in part to its unwillingness to play by the rules of international trade. This, too, is a symptom of its style of governance, whereby secrecy prevails. Indeed, in 2011 the Office of the US Trade Representative challenged the Chinese government in the WTO over its subsidies to wind turbine 
manufacturers that required the use of local content. The dispute was not resolved until China agreed to halt the subsidies (Office of the US Trade Representative 2011). The United States has also successfully prompted China to delink indigenous innovation from government procurement by eliminating preferences for Chinese firms over foreign firms. Additionally, it must be acknowledged that the highest-end technologies in some industries, such as aerospace, micro-electronics, and nuclear energy, are still legally barred from China by United States export control restrictions. ${ }^{8}$ Still, many observers see these capitulations as small bumps in China's road to technology leadership.

\section{Globalization Marches On}

In a globalized era, Chinese companies need not develop every cutting-edge technology on their own; rather, they can undertake mergers and acquisitions as a deliberate strategy, acquiring advanced technologies owned by foreign firms - even if attempts such as the state-run oil giant China National Offshore Oil Corporation (CNOOC)'s bid for Unocal in 2005, and Huawei Technologies' bid for 3Com in 2008, are sometimes thwarted by foreign governments. In general, the value of mergers and acquisitions that involve technology and R\&D capabilities lie in their intellectual property, knowledge, $\mathrm{R} \& \mathrm{D}$ and design processes.

In their study of Chinese mergers and acquisitions, Williamson and Raman (2013) describe how, since 2008, Chinese companies have placed increased emphasis on acquisitions that could deliver new technologies and R\&D capabilities. In particular, they describe how integrating acquisitions involving technology and R\&D is less complicated and less risky as compared with integrating entire organizations:

\footnotetext{
${ }^{8}$ The American Chamber of Commerce in China frequently complains to the United States about this issue because US firms are unable to sell coveted technologies to China, as it is illegal to do so under US law.
} 
Patents and blueprints can be beamed back to China, where a Chinese engineer can easily understand them. R\&D centres involve relatively small numbers of staff. These highly skilled individuals do need very careful management and motivation. But Chinese acquirers' willingness to invest in $\mathrm{R} \& \mathrm{D}$ as part of a strategy to improve their competitive advantage, added to the new prospect of exploiting their innovations in the Chinese market, excites most of the R\&D staff in these acquisitions. (Williamson and Raman 2013:

Interfaces with the Chinese organization, meanwhile, can be kept simple: foreign engineers produce innovative ideas for products and processes, and the Chinese companies use their complementary capabilities to scale up the inventions.

As early as the Tenth Five-Year Plan (2001-2005), the Chinese government unveiled its 'go global' strategy to encourage Chinese companies to invest abroad. However, China's outward foreign direct investment (FDI) did not accelerate conspicuously until the global financial crisis of 2008-2009. In 2012, China's outward FDI amounted to US $\$ 87.8$ billion, ranking it third in the world (Ministry of Commerce of China 2013). Among these outward FDI projects, 457 were for mergers or acquisitions involving foreign companies, whose transaction value amounted to US $\$ 43.4$ billion. The goal of many these projects has quite explicitly been the acquisition of advanced technology, often to be used by the acquirer to strengthen its position inside China (instead of wresting market share from entrenched rivals in mature developed markets), reaping the takeover's benefits quickly in the fastgrowing Chinese market. We offer some illustrative examples below.

In 'high-tech' industry, the Lenovo Group struck two deals in close succession in early 2014. In January, Lenovo agreed to buy IBM's low-end server business for 
US\$2.3 billion ${ }^{9}$ (subject to US government approval). With Lenovo's personal computer business increasingly threatened by smart phones and superfast tablet computers, this deal represents a repositioning of Lenovo as a force in data storage servers. Then, in February, Lenovo agreed to buy Google Inc.'s Motorola handset division for US\$2.91 billion. Billed as China’s largest-ever technology deal, this move represents not only a bold foray into a highly competitive US handset market but also a direct challenge to the very largest global technology firms-Apple Inc. and Samsung Electronics. It continues Lenovo's repositioning as a force in mobile devices (in addition to data storage centers and personal computers).

In December 2009, Beijing Automotive Industry Holding Company Limited (BAIC) announced that it had completed its acquisition of the intellectual property rights of Saab, the Swedish car manufacturer owned by General Motors. BAIC's objective in acquiring Saab was to integrate Saab's technology into its future R\&D operations to develop an indigenous BAIC vehicle. The deal provided BAIC with access to engineers and designers under an agreement whereby Saab will provide assistance to help integrate these technologies into upcoming BAIC vehicles for the Chinese market (Williamson and Raman 2013). BAIC acquired not only the intellectual property rights affiliated with Saab vehicles and engines, but also Saab's entire R\&D, quality management, and supplier development and management systems. Following BAIC's acquisition of Saab, the first indigenous BAIC-brand vehicle developed based on the Saab technology was launched in September 2012 (People's Daily Online 2012).

Also in the automobile industry, the Chinese carmaker Geely completed the acquisition of another Swedish automaker, Volvo, from Ford Motors in August 2010.

\footnotetext{
${ }^{9}$ This deal came nearly a decade after Lenovo bought IBM's then-money-losing ThinkPad business for US\$1.75 billion, eventually becoming the world leader in personal computers in 2012 .
} 
Geely needed Volvo's technology in order to improve the quality of its own brand of cars because of increasing competition in China's auto market (now the world's largest by sales volume). As part of the envisioned technology-sharing model, Geely requires Volvo engineers to help it improve its engineering capabilities. Under the terms of the agreement reached between Geely and Ford Motors, Geely will own all of Volvo's key technologies and intellectual property rights and will also have the right to use some of its intellectual property rights in the fields of auto safety and environmental protection. Intellectual property right ownership represents the core value of this acquisition (Nicholson 2010).

In the aviation industry, China Aviation Industry General Aircraft (CAIGA) the largest general aircraft manufacturer in China — announced in June 2011 that it had completed its acquisition of U.S.-based Cirrus Aircraft. Cirrus is the secondlargest manufacturer of single-engine general aviation aircraft in the world. It has delivered nearly 5,000 piston airplanes over the last decade, and now has a singleengine 'Vision' jet under development. Cirrus said that CAIGA will invest most of the US\$150 million required to complete development of the new jet, which could achieve US Federal Aviation Administration certification and initial deliveries by 2015. By acquiring Cirrus, CAIGA will learn how to build a worldwide sales and marketing network to become a global player. It will also acquire the necessary skills and product lines to open up the Chinese general aviation market (Xin 2011).

In renewable energy, again involving the wind turbine industry, $R \& D$ alliances with upstream firms and, increasingly, mergers and acquisitions, have enabled Chinese firms to supplement indigenous R\&D to master state-of-the-art technologies. Consider, for instance, the R\&D alliance between China's Sinovel and U.S.-based Windtec in 2008, which allowed Sinovel to produce five- and six- 
megawatt turbines in 2010 and 2011 (Fredette 2010). Also in 2008, the Chinese company Goldwind acquired 70 per cent ownership of German-based Vensys Energy, its former partner in collaborative design. This acquisition gave Goldwind access to the world's leading technology and also to professionals in the area of the aforementioned direct-drive permanent magnet wind turbines, not to mention entry into European markets (Liu 2009). Sinovel and Goldwind became the largest manufacturers of wind turbines in China (the second- and third-largest manufacturers globally) in 2011. In 2009 Huiteng Windpower Equipment acquired the Dutch company CT Holding B.V., the parent company of Composite Technology Center, a world-famous blade design firm and former partner of Huiteng in collaborative design. Through this acquisition, Huiteng obtained the design capability of the Composite Technology Center, thereby elevating Huiteng's technological competence to new heights (China Daily 2010).

Similar forays into global acquisition have assisted the machinery industry. For example, Sany Group, China's largest construction equipment manufacturer, acquired the German company Putzmeister, a manufacturer of high-tech concrete pumps, in January 2012. Prior to acquiring Putzmeister, Sany had already, in 2011, opened a greenfield 100 million euro R\&D center near Cologne - the largest Chinese corporate investment in Europe - reflecting its corporate judgment that it needed the best global manufacturing and engineering talent to become a global industry leader. Sany's financial strength would secure Putzmeister's future growth prospects, while the Chinese group would benefit from Putzmeister's cutting-edge technology and acquire a strong distribution and service network outside of China (China Daily 2012). Sany's acquisition of Putzmeister represents the largest takeover by a Chinese company of a family-owned, niche-focused, German Mittelstand firm (that is, a 
small-to-medium-sized enterprise of the sort that forms the backbone of the German economy).

The February 2013 US\$15 billion acquisition of Canadian oil producer Nexen by CNOOC, as well as Sinopec's earlier purchase — in July 2012 —of 49 per cent of the North Sea operations of Talisman Energy, another Canadian oil company, not only secure valuable energy resources for China, but also provide these Chinese firms with advanced production technologies they can use to more efficiently draw oil and gas from nontraditional areas such as deepwater fields and hardened rock formations (Rocha 2013; Kavanagh 2012).

Williamson and Raman (2013) describe how National Chemical Corporation (ChemChina) not only successfully integrated the technology and flow of R\&D from its December 2006 US\$480 million acquisition of the French manufacturer of animal nutrition additives Addiesso Group into their China operations, but also improved their own capability base and scale as a platform for a second 'handspring' into the global market. ChemChina's chairman, Ren Jianxin, calls the strategy 'going out and bringing in'. Williamson and Raman (2013) argue that what ChemChina has done, therefore,

is to acquire foreign technology and know-how and combine it with its own Chinese capabilities in cost innovation and rapid scale-up for the mass market in China, along with its know-how and processes for developing cost-efficient production and distribution processes to create competitive advantage capable of winning market share in China. Once this had been successfully achieved, it has then begun to move on to a second stage in which it takes this newly created competitive advantage and learns to apply and adapt it, backed by its 
capability for large-scale capital investment, to win in markets outside China (p. 274).

Additionally, as Chinese companies improve their technological capabilities, foreign multinational corporations will be increasingly tempted or even compelled by fierce competition to bring their advanced products to, or patent their cutting-edge technologies in, China. Eaton and Kortum (1996) and many other economists suggest that patent flows are an important mechanism of technology diffusion between countries. The intensification of foreign patenting in China suggests that foreign firms are willing to deploy more state-of-the-art technologies in China and accordingly Chinese companies now enjoy a historical, one-off opportunity to absorb technological spillovers and upgrade their own technological capabilities.

Between 1985 and 2005, the proportion of triadic patent families—patents filed in Europe, Japan, and the United States to protect the same invention - that were also filed in China increased from 9 per cent to 61 per cent. This reflects China's rising profile in patent flows insofar as the proportion of triadic patent families that were also filed in other emerging economies such as Brazil, South Africa, Russia, and India has been much lower (less than 20 per cent) and has remained stagnant over the same period. Moreover, China has also replaced Australia and Canada to become the most popular filing destination for triadic patent family patents outside of Europe, Japan, and the United States (Huang and Jacob 2014).

To be sure, many multinational firms will exercise caution before moving all their high-end R\&D or sophisticated technology to China (or other emerging economies) for fear of leaking out frontier technologies due to labor mobility. However, in order not to lose the benefits of being close to market and tapping into the large pool of high-caliber R\&D personnel in emerging economies, many firms 
have developed sophisticated strategies to hedge the risk. These strategies include conducting complementary R\&D in other countries with strong IP protection or conducting R\&D on technologies the commercialization of which depends on firms' proprietary internal resources (Zhao, 2006).

\section{Conclusions}

Even as the world simultaneously marvels at and fears China's growing economic power, too few in policymaking and financial circles anticipate the rise of Chinese multinationals to positions of global technological leadership. To be sure, some Chinese companies have benefitted enormously from monopolies granted by Beijing and continuous improvement of Chinese firms' technological strength relies on political stability in the country. However, more of this dominance should be attributed to China's massive and growing domestic market, strong government support aimed at turning China into an 'innovative nation', and the intensified forces of globalization. These factors, individually and combined, help to explain how and why Chinese multinationals should move with unexpected ease beyond their traditional reliance on low factor-input costs to scale the value-added chain, thereby realizing the country's development and strategic goals based on its burgeoning technological strength. Should such a move indeed occur, it would no doubt have major global implications: global technological leadership has profound implications for economics, national wealth, security and power. Indeed, the Chinese technological threat to existing, pre-established hierarchies and hegemons may mitigate or even reverse current trends in global economic and technological sharing with China. ${ }^{10}$

\footnotetext{
${ }^{10}$ Such geo-political and security concerns are, however, issues that are beyond the scope of this article.
} 
We have shown that, contrary to widespread doubts about China's capacity to achieve a position of technological dominance, the three factors we have identified are already raising the technological profile of Chinese companies, enabling them not only to shed their old low-technology, low-profit mode of operation, but also, more importantly, their bias against innovation through commercialization. The mergers and acquisitions cases are particularly telling because they underscore the extent to which technology transfer to China is now taking place across a broad swath of industries.

In the past, Chinese companies had to be content with acquiring technology through license agreements or joint ventures with foreign partners. In most cases, these arrangements limited the use of technology by Chinese firms. When a Chinese company acquires an overseas counterpart outright, however, it owns the underlying technology and can use it as it wishes-domestically or internationally. Furthermore, overseas acquisitions represent a point of pride in China, showcasing its rising economic strength and signaling both Chinese triumph and the decline of its Western counterparts.

To be sure, given the sheer size of the Chinese economy, there will always remain a portion of firms whose goals are best served at the low end of the value chain. Now, however, many other firms are moving up the value-added chain in an ongoing process that is rapidly accelerating. While Chinese companies are widely acknowledged to have mastered the 'downstream' end of product innovationtesting, prototyping, developing, marketing and making subsequent product improvements - the rising strength of basic $R \& D$, combined with the increasing size of China's economy, government support, and intensified globalization have Chinese companies rising to a level that is on par with their counterparts in the United States, 
Germany and Japan. Indeed, given the similarities we have noted between America's rise to technological dominance in the twentieth century and the forces at work in China today, we are likely to see history repeat itself, ushering in an age of Chinese global technological leadership. 


\section{REFERENCES}

Abramovitz, Moses (1962) 'Economic growth in the United States', American Economic Review 52: 762-782.

Abramovitz, Moses (1986) 'Catching Up, Forging Ahead, and Falling Behind', The Journal of Economic History 46/2: 385-406.

Adam, S. (2010) 'China May Surpass US by 2020 in Super Cycle, Standard Chartered Says', Bloomberg News, November 14, http://www.bloomberg.com/news/2010-11-15/china-amay-surpass-u-s-by2020-in-super-cycle-standard-chartered-says.html, accessed 11 September 2012.

Ames, Edward, and Nathan Rosenberg (1963) 'Changing Technological Leadership and Industrial Growth’, Economic Journal 72: 13-31.

Anderlini, J. (2013) 'Justin Lin Criticizes China Growth Pessimists', Financial Times, July 29, http://www.ft.com/cms/s/0/3e62c9de-f83e-11e2-b4c400144feabdc0.html\#axzz2fQhx YdcZ, accessed 14 September 2012.

Brandt, L., Thun, E. (2010) The Fight for the Middle: Upgrading, Competition, and Industrial Development in China. World Development 38, 1555-1574.

Breznitz, Dan, and Murphee, Michael (2011) Run of the Red Queen: Government, Innovation, Globalization and Economic Growth in China. Yale University Press: New Haven.

Cao, Cong, Suttmeier, Richard and Simon, Denis Fred (2006) "China's 15-Year Science and Technology Plan", Physics Today, 59, 38-43.

Chandler, Alfred, D. Jr. (1977) The Visible Hand: The Managerial Revolution in American Business. Belknap Press: Cambridge, Massachusetts.

China Daily (2012) 'BAIC Buys Saab Assets from GM', People's Daily Online, 15 December, http://english.people.com.cn/90001/90778/90862/6842322.html, accessed 18 September 2012.

China Daily (2010) 'China's Top Wind Blade Maker Eyes US Growth', China Daily, 18 May, http://www.chinadaily.com.cn/bizchina/201005/18/content_9863958.htm, accessed 26 September 2012.

China Daily (2012) 'Sany Acquires German Truck Mixer Maker', China Daily, 25 July 25, http://www.chinadaily.com.cn/business/201207/25/content_15615633.htm, accessed 18 September 2012.

Chinese Wind Energy Association (2014) '2013 Statistics of China Wind Energy Installed Capacity', Beijing: Chinese Wind Energy Association. 
Denison, E., and J. Poullier (1967) Why Growth Rates Differ. Brookings Institution: Washington.

Eaton, J. and Kortum, S. (1996), Trade in Ideas-Patenting and Productivity in the OECD, Journal of International Economics, 40, 3-4, 251-278.

Economist (2011). 'How to Get a Date: The Year When the Chinese Economy will Truly Eclipse America's is in Sight', Economist, December 31, 2011, http://www.economist.com/node/21542155, accessed 26 September 2012.

Fagerberg, Jan, Mowery, David and Richard R. Nelson (2005) The Oxford handbook of innovation. Oxford University Press: Oxford.

Fredette, J. (2010) 'AMSC and Sinovel Expand Strategic Partnership', Business Wire, 25 May, http://www.businesswire.com/news/home/20100525005094/en/AMSCSinovel-Expand-Strategic-Partnership, accessed 27 September 2012.

Freeman, Christopher (1987) Technology, policy, and economic performance: Lessons from Japan. Pinter Publishers: London.

Friedman, Thomas (2012) 'In China We (Don't) Trust', New York Times, 11 September, Sec. A: 31.

Gilboy, George G. (2004) 'The Myth behind China's Miracle', Foreign Affairs 83/4: $33-48$.

Goldman Sachs (2010) 'The New Geography of Global Innovation', Goldman Sachs Global Market Institute.

Grupp, H., and Hofmeyer (1986) 'A Technometric Model for the Assessment of Technological Standards and Their Application to Selected Technology Comparisons', Technological Forecasting and Social Change 30: 123-137.

Habakkuk, H. J. (1962) American and British Technology in the Nineteenth Century: The Search for Labour-Saving Inventions. Cambridge University Press: Cambridge.

Hobday, Michael (1995) Innovation in East Asia: The challenge to Japan. Edward Elgar: Aldershot, England.

Hounshell, David (1984) From the American System to Mass Production, 1800-1932: The Development of Manufacturing Technology in United States. John Hopkins University Press: Baltimore.

Huang, Can, and Jacob, JoJo (2014) 'Determinants of Quadic Patenting: Market Access, Imitative Threat, Competition and Strength of Intellectual Property Rights', Technological Forecasting and Social Change, available online 29 April, doi: 10.1016/j.techfore.2013.04.004. 
Institute of Scientific and Technical Information of China (2013). Statistical Data of Chinese S\&T Papers 2013. Accessed on January 7th, 2015, available at:< http://www.istic.ac.cn/portals/0/documents/kxpj/1\%E6\%96\%B0\%E9\%97\%B $\mathrm{B} \% \mathrm{E} 7 \% \mathrm{~A} 8 \% \mathrm{BF} . \mathrm{pdf}>$

Kavanagh, M. (2012) 'Sinopec Strikes Deal with Talisman Energy', Financial Times, 23 July, http://www.ft.com/intl/cms/s/0/59a466c4-d4ce-11e1-944400144feabdc0.html\#axzz2fQhxYdcZ, accessed 26 September 2012.

Kindleberger, Charles, P. (1961, August) 'Obsolescence and Technical Change', Oxford Institute of Statistics Bulletin: 281-297.

Kranzberg, Melvin (1967) Technology in Western Civilization Vol. I. Oxford University Press: Oxford.

Lall, Sanjaya (1997) 'Technology Development Policies: Lessons from Asia'. In Learning from the Asian Tigers. St. Martin's Press: New York: 59-105.

Lazonick, W. (1988, September) 'Business Organization and Competitive Advantage: Capitalist Transformations in the Twentieth Century', Mimeo. Columbia University.

Lewis, Joanna (2011) 'Building a National Wind Turbine Industry: Experience from China, India and South Korea', International Journal of Technology and Globalisation 5/3-4: 281-305, http://www.chinadaily.com.cn/bizchina/200912/15/content_9178876.htm, accessed 18 September 2012.

Li, Ping Peter (2013) (Ed.) Disruptive Innovation in Chinese and Indian Businesses The Strategic Implications for Local Entrepreneurs and Global Incumbents. Routledge: London.

Lind, Michael (2012) Land of Promise: An Economic History of the United States. Harper: New York.

Liu, Y. (2009) 'Goldwind to Spread Wings Overseas for Growth'. China Daily, 15 December, http://www.chinadaily.com.cn/bizchina/200912/15/content_9178876.htm, accessed 26 September 2012.

Maddison, Angus (1982) Phases of Capitalist Development. Oxford University Press: Oxford.

Mansfield, E (1989) 'The Diffusion of Industrial Robots to Japan and in the United States’, Research Policy 18: 183-192.

Ministry of Commerce of China (2013) Publication of the 2012 Statistical Bulletin of China's Outward Foreign Direct Investment. Beijing: Ministry of Commerce of China, http://www.gov.cn/gzdt/2013-09/09/content_2484724.htm, accessed January 9, 2015. 
Ministry of Science and Technology, 2014. Publication on National Science and Technology Expenditure in 2013, (2013 Nian Quan Guo Ke Ji Jing Fei Tou $\mathrm{Ru}$ Tong Ji Gong Bao), accessed on January 7th, 2015, available at:< http://www.most.gov.cn/kjtj/tjbg/201411/t20141102_116442.htm>.

Mokyr, Joel (1990) The lever of riches: Technological creativity and economic progress. Oxford University Press: New York.

National Bureau of Statistics of China (2013) China Statistical Yearbook 2013. Beijing: China Statistics Press.

National Development and Reform Commission (2006) 'Initiative on Promotion of Development of Wind Power Industry'. Beijing: National Development and Reform Commission, http://www.xny360.net/news/10818281.html, accessed 18 September 2012.

National Science Foundation (2012) National Science Board Science and Engineering Indicators 2012. Arlington VA: National Science Foundation [NSB 12-01].

National Science Foundation (2014) National Science Board Science and Engineering Indicators 2014. Arlington VA: National Science Foundation [NSB 14-01].

Nelson, Richard R. (1990) 'US Technological Leadership: Where Did It Come From and Where Did it Go?' Research Policy, 30: 117-132.

Nelson, Richard R., and Wright, Gavin (1992) 'The Rise and Fall of American Technological Leadership: The Postwar Era in Historical Perspective'. Journal of Economic Literature, 30/4: 1931-64.

Nicholson, C. V. (2010) 'Chinese Carmarker Geely Completes Acquisition of Volvo from Ford'. New York Times, 22 August, Sec. B: 3.

OECD (2014) Main Science and Technology Indicators Database, June 2014, http://stats.oecd.org/BrandedView.aspx?oecd_bv_id=strd-data-en\&doi=data00182-en; accessed 6 Jan 2015

Office of the US Trade Representative (2011) 'China Ends Wind Power Equipment Subsidies Challenged by the United States in WTO Dispute', Washington, DC: Office of the U. S. Trade Representative, http://www.ustr.gov/aboutus/press-office/press-releases/2011/june/china-ends-wind-power-equipmentsubsidies-challenged, accessed 11 September 2012.

Rocha, E. (2013) 'CNOOC Closes \$15.1 Billion Acquisition of Canada's Nexen', Reuters, 25 February 25, http://www.reuters.com/article/2013/02/25/us-nexencnooc-idUSBRE91O1A420130225, accessed 14 September 2012.

Schmookler, Jacob (1966) Invention and Economic Growth. Cambridge, MA: Harvard University Press. 
Shambaugh, David (2012) 'Are China's Multinational Corporations Really Multinational?’ East Asia Forum 4/2: 7-9.

Solow, Robert M. (1956) 'A Contribution to the Theory of Economic Growth', Quarterly Journal of Economics 70/1: 65-94.

de Tocqueville, Alexis (2002) Democracy in America. University of Chicago Press: Chicago.

Takeuchi, H., and Nonaka, I. (1986) 'The New Product Development Game', Harvard Business Review Jan/Feb: 285-305.

Thomson Reuters (2011) Top 20 Countries in All Fields, 2011-August 31, 2011, http://archive.sciencewatch.com/dr/cou/2011/11decALL/, Accessed February $12,2014$.

US Patent and Trademark Office (2014) Number of Utility Patent Applications Filed in the United States, By Country of Origin, Calendar Years 1965 to Present. Washington DC: USPTO, available at http://www.uspto.gov/web/offices/ac/ido/oeip/taf/appl_yr.htm, accessed on January 15, 2015.

Veblen, Thorstein (1939) Imperial Germany and the Industrial Revolution. Greenwood Press: Westport, Connecticut.

Williamson, Peter and Raman, Anand P. (2013) 'Cross-Border M\&A and Competitive Advantage of Chinese EMNEs' in Williamson, Peter J. et al., The competitive advantage of emerging market multinationals. Cambridge University Press: UK.

Womack, J., Jones, D., and Roos, D. (1990). The Machine That Changed The World. Simon and Schuster: New York.

World Intellectual Property Organization (2013) 2013 PCT Yearly Review. Geneva: World Intellectual Property Organization, http://www.wipo.int/export/sites/www/freepublications/en/patents/9 01/wipo pub 901 2013.pdf, accessed February 2014.

Xin, D. (2011) 'CAIGA Acquires US Planemaker in Historical Deal', China Daily, 2 March, http://www.chinadaily.com.cn/bizchina/201103/02/content_12100591.htm, accessed 14 September 2012.

Xinhua News Agency (2012) 'Chinese Top Leaders Call for Innovation in Science, Technology. Xinhua News Agency, July 7, http://www.gov.cn/ldhd/201207/07/content_2178574.htm, accessed 11 September 2012.

Xinhua News Agency (2013) 'Minister of Industry and Information Technology: China's Output of More than 220 Industrial Products are Ranked $1^{\text {st }}$ in the World', http://news.xinhuanet.com/fortune/2013-03/26/c 115153816.htm, accessed 18 September 2012. 